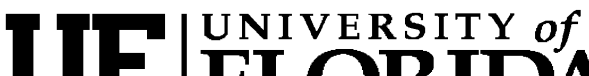 FLORIDA \\ IFAS Extension
}

\section{New Options for Managing Weeds in the Landscape ${ }^{1}$}

\section{Dr. J. Bryan Unruh and Dr. Barry J. Brecke ${ }^{2}$}

Weeds continue to be major problems in Florida's landscapes and turf managers struggle to keep them under control. When managing weeds, the first and best method of weed control begins with proper management practices that encourage a dense, thriving turf. Healthy turf shades the soil so sunlight cannot reach weed seeds that are ready to germinate. A thick turf also minimizes the physical space available for weeds to become established. There are several management practices that will promote a healthy, dense grass. These include: proper turfgrass selection, proper cultural practices, traffic control, and pest control.

\section{Proper Turfgrass Selection}

The first management decision is selection of the best turf species or variety for a particular area. For example, areas heavily shaded will support only a few turfgrass species. Growing Bermudagrass or bahiagrass under any shade will result in thin, weak turf which is very susceptible to weed invasion. Alternate grass choices for shady conditions include certain cultivars of St. Augustinegrass or zoysiagrass.

\section{Proper Cultural Practices}

Proper fertilization, watering, mowing, and control of other pests are required to produce a dense turf that will prevent weed infestation. If turf is overor under-watered, over- or under-fertilized, or mowed too low or too infrequently, the turf is weakened and cannot compete with weeds. Damaged areas resulting from using unsharpened mower blades increase the time needed for turf recovery, allowing for weed invasion. It is very important to understand that weeds do not create a void, they fill a void. Any cultural practice that reduces the vigor and health of the turf will encourage weed infestations.

\section{Traffic Control}

Turf damaged by foot or vehicle traffic also invites weeds. Turf compacted by excess traffic, especially when the soil is water saturated, cannot easily extract the needed oxygen. Goosegrass, annual bluegrass, and certain sedges are weeds that grow well in compacted soils and/or continuously wet areas. The first steps to managing weeds in such a situation are to install drainage and alleviate the soil compaction through core aeration.

1. This document is ENH1039, one of a series of the Environmental Horticulture Department, Florida Cooperative Extension Service, Institute of Food and Agricultural Sciences, University of Florida. Original publication date June 29, 2006. Please visit the EDIS web site at http://edis.ifas.ufl.edu.

2. J.B. Unruh, Associate Professor, Turfgrass Specialist, and B.J. Brecke, Weed Science/Associate Center Director, West Florida Research and Education Center, Institute of Food and Agricultural Sciences, Jay, FL 32565

All chemicals should be used in accordance with directions on the manufacturer's label. Use pesticides safely. Read and follow directions on the manufacturer's label. The use of trade names in this publication is solely for the purpose of providing specific information. UF/IFAS does not guarantee or warranty the products named, and references to them in this publication does not signify our approval to the exclusion of other products of suitable composition.

The Institute of Food and Agricultural Sciences (IFAS) is an Equal Opportunity Institution authorized to provide research, educational information and other services only to individuals and institutions that function with non-discrimination with respect to race, creed, color, religion, age, disability, sex, sexual orientation, marital status, national origin, political opinions or affiliations. U.S. Department of Agriculture, Cooperative Extension Service, University of Florida, IFAS, Florida A. \& M. University Cooperative Extension Program, and Boards of County Commissioners Cooperating. Larry Arrington, Dean 


\section{Other Pest Control}

Turf damaged by insects and disease does not always recuperate quickly enough to outcompete germinating weeds. Specifically, St. Augustinegrass infested with chinch bugs or the sugarcane grub has thinned, open areas which are usually slow to recover, thus enabling weeds to become established. Areas with take-all root rot often become infested with troublesome weeds. Similarly, high nematode populations also thin the turf and make it less able to recuperate from environmental stresses. Weeds that often become established in nematode-infested soil include spotted spurge and Florida pusley.

Even when managing turf under optimal conditions, Florida's unique environment presents challenges in and of itself. Our very active hurricane seasons over the past two years have greatly impacted weed management. We are often asked to identify weeds that have never been observed in the landscape before. Without a doubt, many of these infestations can be attributed to the extreme weather patterns. Fortunately, several new herbicides have been introduced. These weed management tools will help the turf manager battle problematic weeds.

\section{Certainty $^{\mathrm{TM}}$}

Certainty ${ }^{\mathrm{TM}}$ (sulfosulfuron) is a new selective postemergence herbicide from Monsanto used for the control of annual and perennial grass, broadleaf, and sedge species. Certainty ${ }^{\mathrm{TM}}$ is one of the few newly registered sulfonylurea herbicides that can be safely used on St. Augustinegrass and centipedegrass. In our research trials at UF, Certainty ${ }^{\mathrm{TM}}$ has provide excellent purple and yellow nutsedge control, as well as control of kyllinga and other broadleaf and grass species. Certainty ${ }^{\mathrm{TM}}$ is labeled for use on lawns, sod farms, cemeteries, golf courses, and any other highly managed commercial or residential turf.

\section{Escalade $^{\mathrm{TM}}$, Escalade $2^{\mathrm{TM}}$, and Escalade Low Odor $^{\mathrm{TM}}$}

Escalade $^{\mathrm{TM}}$, Escalade 2 ${ }^{\mathrm{TM}}$, and Escalade Low Odor $^{\mathrm{TM}}$ (Nufarm Americas Inc.) are selective broadleaf weed herbicides that contain 2,4-D, fluroxypyr, and dicamba. These three products are safe for use on bahiagrass, Bermudagrass and zoysiagrass but will cause significant injury to centipedegrass and St. Augustinegrass, especially 'Floratam.' Escalade $2^{\mathrm{TM}}$ has a reduced rate of fluroxypyr. These three combination products have not been evaluated by these authors.

\section{Monument $^{\mathrm{TM}}$}

Monument $^{\mathrm{TM}}$ (trifloxysulfuron) is a selective postemergence herbicide from Syngenta used for the control of certain weeds in commercial warm-season turfs, including golf courses, sod farms and commericial lawns. Also a sulfonylurea herbicide, Monument ${ }^{\mathrm{TM}}$ has been tested extensively by these authors and it provides excellent control of a broad range of weeds including all sedge species, green kyllinga, oxalis and various other grass and broadleaf species in Bermudagrass and zoysiagrass. Monument ${ }^{\mathrm{TM}}$ cannot be used on St. Augustinegrass, bahiagrass, or centipedegrass.

\section{ProClipse $^{\mathrm{TM}}$}

ProClipse $^{\mathrm{TM}}$ (Nufarm Americas Inc.) is a generic formulation of prodiamine, the same active ingredient as in Barricade ${ }^{\mathrm{TM}}$. This non-staining active ingredient provides preemergence control of crabgrass, goosegrass, foxtail, and Poa annua, and is effective on other problem grassy and broadleaf weeds such as annual bluegrass, henbit, knotweed, chickweed and spurge. ProClipse ${ }^{\mathrm{TM}}$ does not have postemergence activity and thus will not control the hard-to-control grassy weeds such as India crabgrass, blanket crabgrass, and tropical signalgrass that survive the mild winters in Florida. ProClipse ${ }^{\mathrm{TM}}$ is safe for use on all warm-season turf species grown in Florida.

\section{Revolver ${ }^{\mathrm{TM}}$}

Revolver ${ }^{\mathrm{TM}}$ (foramsulfuron) is a postemergence herbicide from Bayer Environmental Sciences that selectively removes cool-season annual and perennial grasses from Bermudagrass and zoysiagrass but not St. Augustinegrass, bahiagrass, or centipedegrass. Much of our research has focused on using Revolver ${ }^{\mathrm{TM}}$ for overseed removal and for Poа аппиа control prior to overseeding. Of the aforementioned herbicides, Revolver's ${ }^{\mathrm{TM}}$ activity on goosegrass is notable and it provides a great option for controlling 
goosegrass in Bermudagrass and zoysiagrass.

Revolver ${ }^{\mathrm{TM}}$ is intended for professional use on home lawns, golf course turf, sports fields, commercial lawns, cemeteries, parks, campsites, recreational areas, roadsides, school grounds, and sod farms.

\section{SedgeHammer ${ }^{\mathrm{TM}}$}

SedgeHammer ${ }^{\mathrm{TM}}$ (halosulfuron) is a selective herbicide for use in controlling nutsedge in turf and landscaped areas and in landscaped areas with established woody ornamentals. New to Gowan Company, SedgeHammer ${ }^{\mathrm{TM}}$ contains the same active ingredient previously marketed as Manage ${ }^{\mathrm{TM}}$ turf herbicide by Monsanto. SedgeHammer ${ }^{\mathrm{TM}}$ effectively controls both yellow and purple nutsedge in cool- and warm-season turfgrasses with demonstrated safety to most turfgrass species.

\section{Surge $^{\mathrm{TM}}$}

Surge ${ }^{\mathrm{TM}}$ (PBI/Gordon Corp.) contains sulfentrazone, a new active ingredient in turf weed control, along with 2,4-D, MCPP and dicamba. Surge ${ }^{\mathrm{TM}}$ provides control of broadleaf weeds including spurge and other warm-season weeds such as knotweed, plantain, oxalis, clover and dandelion. Additionally, Surge ${ }^{\mathrm{TM}}$ provides suppression of young and actively growing yellow nutsedge. Surge ${ }^{\mathrm{TM}}$ should not be applied when temperatures exceed $90^{\circ} \mathrm{F}$ or when the turf is under stress. Surge ${ }^{\mathrm{TM}}$ can be used on Bermudagrass, zoysiagrass, bahiagrass and buffalograss but not St. Augustinegrass. This combination product has not been evaluated by these authors.

\section{Conclusion}

Although most of these products are safe for use on Bermudagrass and zoysiagrass, most will cause injury to St. Augustinegrass and centipedegrass, the predominant lawn grasses in Florida. Similarly, a herbicide is desperately needed to replace Asulox ${ }^{\mathrm{TM}}$, which was removed from the marketplace several years ago. In the absence of such a product, turf managers will have to focus more on cultural management strategies to ward off these troublesome weeds. 